\title{
KARAKTERISASI, PENCIRI DAN KEUNGGULAN POHON INDUK DUKU PRUNGGAHAN TUBAN
}

\section{CHARACTERIZATION, IDENTIFY, AND SUPERIORITY OF DUKU PRUNGGAHAN TUBAN}

\author{
Baswarsiati $^{1)}$ dan Enny Sumaryati ${ }^{2)}$ \\ 1) Balai Pengkajian Teknologi Pertanian Jawa Timur \\ 2) Fakultas Pertanian Universitas Widyagama Malang \\ Email :baswarsiati@gmail.com
}

\begin{abstract}
ABSTRAK
Salah satu buah unggulan di Kabupaten Tuban adalah duku Varietas Prunggahan Tuban yang telah dikenal oleh masyarakat Tuban dan sekitarnya sejak ratusan tahun lalu. Duku Prunggahan Tuban memiliki ukuran buah yang besar, rasa buah manis dan segar. Kadar gulanya tinggi $\left(19-21^{\circ}\right.$ Brix) dan kadar asamnya rendah, kulit buah tipis dan lemas, warna daging buah jernih/bening. Duku ini mampu tumbuh dan berproduksi di dataran rendah dekat laut walau pada umumnya tanaman duku tumbuh dan berproduksi pada ketinggian $400 \mathrm{~m}-700 \mathrm{~m}$ dari permukaan laut dengan lingkungan yang baik dan ternaungi, sehingga duku Prunggahan Tuban tumbuh baik di desa Prunggahan Wetan, Prunggahan Kulon dan Desa Semanding Kecamatan Semanding, Kabupaten Tuban dengan ketinggian tempat 4-10 m dpl. Seluruh luas areal dari ketiga desa di Kecamatan Semanding merupakan sentra tanaman duku seluas sekitar 149 hektar. Jumlah tanaman yang sudah berproduksi sebanyak 287 pohon dengan umur antara 15 tahun hingga 150 tahun lebih, dan tanaman yang belum berproduksi dengan umur di atas 10 tahun sekitar 209 pohon. Potensi duku Prunggahan Tuban terletak pada kualitas buah yang unggul, produksi tinggi serta nilai ekonomis yang tinggi. Pohon duku yang baru pertama kali berbuah yang ditanam dari bebih (umur 14- 15 tahun) dapat menghasilkan buah sebanyak 40-50 kg, pada umur 20 tahun menghasilkan $80-150 \mathrm{~kg}$ buah, serta tanaman yang telah berumur lebih dari 50 tahun mampu menghasilkan 300$500 \mathrm{~kg}$ buah per pohon. Tanaman yang dipelihara secara intensif dapat menghasilkan buah hingga $500 \mathrm{~kg} /$ pohon.
\end{abstract}

Kata Kunci : Duku, karakterisasi, Prunggahan Tuban

\begin{abstract}
One of the superior fruit in Tuban district is Prunggahan Tuban Lansium which has been known by the people of Tuban and its surrounding since hundreds of years ago. Prunggahan Tuban Lansium has large fruit size, sweet taste, and fresh fruit. It contains high sugar content $\left(19-21^{\circ}\right.$ Brix), and low acid content, thin and supple skin, and clear color flesh. It is able to grow and produce in the lowlands near the sea though generally it grows and produces at an altitude of $400 \mathrm{~m}-700 \mathrm{~m}$ above sea level with good environment and shaded place, so Prunggahan Tuban Lansium can grow well in
\end{abstract}


Prunggahan Wetan village, Prunggahan Kulon and Semanding village Semanding sub district, Tuban district whose altitude is $4-10 \mathrm{~m}$ asl. The entire area of the three villages in the district Semanding which is the center of the lansium plant which are around 149 hectares. The number of plants that have been producing are 287 trees with ages between 15 to more than 150 years, and plants that have not been producing with age above 10 years are about 209 trees. The potentials of Prunggahan Tuban Lansium are its superior fruit quality, high production and economic value. Lansium tree which planted from the seed (aged 14-15 years) can produce fruits as many as $40-50 \mathrm{~kg}$. At the age of 20 years it can produce $80-150 \mathrm{~kg}$ and plants that have been aged more than 50 years can produce $300-500 \mathrm{~kg} /$ tree. In intensive crops it can produce up to $500 \mathrm{~kg}$ of fruit per tree.

Keywords : characterization, Lansium, Prunggahan Tuban

\section{PENDAHULUAN}

\section{Duku (Lansium domesticum)} merupakan salah satu komoditas buahbuahan yang berpeluang untuk dikembangkan karena memiliki nilai ekonomis cukup tinggi. Duku berasal dari Asia Tenggara bagian Barat, dari semenanjung Thailand di Sebelah Barat sampai Kalimantan (Verheij dan Coronel, 1997). Varietas duku yang ada di Indonesia tidak banyak bila dibandingkan dengan tanaman buah lainnya seperti durian, mangga, dan jeruk. Salah satu duku yang terkenal di Kabupaten Tuban yaitu varietas Prunggahan Tuban. Duku Prunggahan Tuban telah dikenal oleh masyarakat Tuban dan sekitarnya sejak ratusan tahun yang lalu. Duku Prunggahan Tuban merupakan produk unggulan Tuban karena memiliki rasa buah yang sangat manis, buah berukuran besar, kulit buah tipis dan lemas, warna daging buah jernih/bening serta yang sangat spesifik yaitu mampu tumbuh dan ber produksi di dataran rendah dekat laut.

Pada umumnya tanaman duku tumbuh dan berproduksi pada ketinggian 400m - 700m dari permukaan laut dengan lingkungan yang baik dan ternaungi (Verheij dan Coronel, 1997), tetapi duku Prunggahan Tuban tumbuh baik di Desa Prunggahan Wetan, Prunggahan Kulon dan Desa Semanding Kecamatan Semanding, Kabupaten Tuban dengan ketinggian tempat 4-10 m dpl. Seluruh luas areal dari ketiga desa di Kecamatan Semanding yang merupakan sentra tanaman duku tersebut sekitar 149 hektar. Sedangkan jumlah tanaman yang sudah berproduksi sebanyak 287 
pohon dengan umur di atas 15 tahun hingga 150 tahun lebih, dan tanaman yang belum berproduksi dengan umur di atas 10 tahun sekitar 209 pohon. Tanaman yang masih remaja dan berumur 1-2 tahun sekitar 1000 pohon (KIPPK Tuban, 2004).

Potensi duku Prunggahan Tuban terletak pada kualitas buah yang unggul, produksi tinggi serta nilai ekonomis yang tinggi. Pohon duku yang baru pertama kali berbuah asal dari biji (umur 14-15 tahun) dapat menghasilkan buah sebanyak 40-50 kg, pada umur 20 tahun menghasilkan 80-150 kg serta tanaman yang telah berumur lebih dari 50 tahun mampu menghasilkan 300 sampai $500 \mathrm{~kg} /$ pohon. Pada tanaman yang dipelihara secara intensif dapat menghasilkan buah hingga $500 \mathrm{~kg}$ per pohon. Bila rata-rata tanaman duku menghasilkan $200 \mathrm{~kg} /$ pohon dan harga buah duku di Tuban pada tahun 2015 sekitar Rp 20.000-,- per kilogram di tingkat petani, maka satu tanaman dapat menghasilkan sekitar Rp 4.000.000,-

\section{METODE PENELITIAN}

Seleksi dan karakterisasi untuk menentukan Pohon Induk Tunggal dilakukan tahun 2015 di Kecamatan Semanding, Kabupaten Tuban. Metode yang digunakan dengan melakukan pengamatan di lapang serta wawancara dengan melibatkan secara aktif peranan petani, peneliti, penyuluh, aparat setempat, pihak BPTP Jawa Timur, BPSBTPH dan ВPTPH serta pihak KIPPK Kabupaten Tuban. Wawancara langsung menggunakan responden petani pemilik tanaman duku ataupun pedagang duku Prunggahan Tuban.

Pengamatan morfologi tanaman di lapang secara umum untuk seleksi awal dilakukan pada populasi tanaman yang ada di Desa Prunggahan Wetan, Kecamatan Semanding, Kabupaten Tuban. Identifikasi dan karakterisasi tanaman dilakukan di lapang dan sebagian materi diamati di laboratorium BPTP Jawa Timur.

Inventarisasi keragaan serangan organisme pengganggu tumbuhan (OPT) pada tanaman duku dilaksanakan bersamaan dengan seleksi pohon induk yang ada di tiga lokasi yaitu Desa Prunggahan Wetan, Prunggahan Kulon, dan Semanding. Pengkajian dilaksanakan selama 1 tahun mulai Januari s/d Desember 2015. 
Pengamatan dilaksanakan sebanyak tiga kali. Pertama, dilakukan observasi mengenai kondisi serangan OPT di lokasi Prunggahan Wetan. Kedua, dilakukan observasi kondisi serangan OPT di lokasi Semanding, dan ketiga dilakukan observasi dan pengamatan pada tiga lokasi. Penentuan tanaman contoh dilakukan secara purporsif di masing-masing lokasi. Setiap lokasi diambil tanaman contoh sebanyak 15 tanaman.

\section{HASIL DAN PEMBAHASAN} Proses Seleksi dan Karakterisasi

Duku Prunggahan Tuban mampu tumbuh dan berkembang di tiga desa yaitu Prunggahan Kulon, Prunggahan Wetan dan Semanding di Kecamatan Semanding Kabupaten Tuban. Berdasarkan asal-usulnya duku merupakan tanaman yang sudah ada sejak ratusan tahun yang lalu (jaman Ronggolawe) dan berdasarkan cerita masyarakat di sekitar lokasi, buah duku tersebut merupakan buah kesukaan para Raja dan Bupati.

Tanaman duku yang ada di masyarakat diperbanyak secara generatif menggunakan biji sehingga peluang terjadinya variasi sangat besar dalam satu populasi. Oleh karena itu seleksi dilakukan dengan seleksi masa positif berdasarkan sifat-sifat tanaman yang mudah dilihat dan diukur (Allard, 1989). Berdasarkan penampakan morfologi maka kegiatan seleksi yang dilakukan meliputi karakter tanaman dengan kriteria tanaman sehat dan tumbuh kekar, karakter daun berdasarkan jumlah dan ukuran, sedangkan karakter produksi tanaman meliputi kuantitas dan kualitas. Hal ini selaras dengan Susilawati (2017) yang meneliti mengenai morfologi tanaman duku dari Sumatra Selatan dengan variabel pengamatan yang lebih mendalam yang meliputi warna daun, luas daun, tinggi tanaman, diameter batang, jumlah stomata, dan jumlah klorofil daun, panjang daun, lebar daun, kadar sukrosa pada daun, dan morfologi daun.

Pelaksanaan karakterisasi dilakukan dengan mengadakan pengamatan secara langsung pada pertanaman duku milik petani di sentra produksi Kecamatan Semanding Kabupaten Tuban. Dari data yang ada berdasarkan produktivitas tanaman duku di tiga desa kecamatan Semanding ditentukan 
populasi dari $10 \%$ tanaman yang memiliki produktivitas tinggi yaitu lebih dari $100 \mathrm{~kg} /$ pohon/tahun (Tabel 1). Pemilik tanaman duku yang namanya tertera pada Tabel 1 memiliki tanaman duku lebih dari satu bahkan ada yang sampai sembilan. Namun tanaman duku yang dipilih dari satu orang pemilik yang memiliki produksi tinggi.

Dari tampilan data produksi yang disajikan pada Tabel 1 maka terpilih tiga tanaman dengan produksi yang tertinggi yaitu milik Bapak Slamet Wahyudi, Ibu Marpuah dan Bapak Budi Sulistono. Ketiga pemilik tanaman tersebut memiliki jumlah tanaman duku lebih dari satu. Bapak Slamet Wahyudi memiliki empat tanaman, bapak Budi memiliki tujuh tanaman dan ibu Marpuah memiliki lima tanaman. Namun dari seleksi awal, dari masingmasing pemilik tersebut hanya terpilih satu tanaman yang mewakili dari keragaan produktivitas tinggi dan keragaan tanaman lebih vigour dan kekar. Contohnya tanaman ibu Marpuah yang terseleksi karena tanaman tersebut merupakan tanaman awal (induk awal) dari duku Prunggahan dengan umur tanaman 200 tahun dan produksi masih cukup tinggi. Sedangkan tanaman terseleksi milik Bapak Wahyudi karena produksi tinggi dan umur lebih tua serta tanaman lebih kekar dibanding tanaman lainnya. Demikian juga tanaman yang terseleksi dari Bapak Budi karena produksi dan keragaan tanaman lebih baik dibanding enam tanaman lainnya.

Setelah ditentukan tanaman dengan produktivitas tinggi maka dilakukan penilaian lanjutan tanaman berdasarkan informasi dari informan kunci dan melihat kondisi di lapang berhubungan dengan keragaan vegetatif tanaman meliputi: kekekaran batang utama, kerapatan percabangan, kesehatan tanaman dan preferensi konsumen seperti pada Tabel 2.

Selanjutnya ketiga tanaman tersebut dipilih lebih lanjut untuk menjadi pohon induk. Penilaian dilakukan berdasarkan karakter umur tanaman, keragaan tanaman, kondisi percabangan, produksi, kesukaan konsumen terhadap kualitas buah, dan kesehatan tanaman. Penilaian tersebut disajikan pada Tabel 2. 
Tabel 1. Keragaan Pertanaman terpilih dari 3 desa: Semanding, Prunggahan Wetan dan Krunggahan Kulon, Kecamatan Semanding, Kabupaten Tuban

\begin{tabular}{|c|c|c|c|}
\hline No & Nama Pemilik & Desa & Produksi $(\mathrm{kg}) /$ pohon/tahun \\
\hline 1 & Taslim & Prunggahan Kulon & 100 \\
\hline 2 & Sunar & Prunggahan Kulon & 175 \\
\hline 3 & Pasri & Prunggahan Kulon & 150 \\
\hline 4 & Lasidin & Prunggahan Kulon & 170 \\
\hline 5 & Hariyono & Prunggahan Kulon & 100 \\
\hline 6 & Munandar & Prunggahan Kulon & 120 \\
\hline 7 & Sukiman & Prunggahan Kulon & 100 \\
\hline 8 & Tamsiran & Semanding & 170 \\
\hline 9 & Sarjan & Semanding & 160 \\
\hline 10 & Tasirin & Semanding & 100 \\
\hline 11 & Daim & Semanding & 200 \\
\hline 12 & Karmadi & Semanding & 200 \\
\hline 13 & Darto & Semanding & 120 \\
\hline 14 & Sumaji & Semanding & 150 \\
\hline 15 & Suparno & Semanding & 170 \\
\hline 16 & Lik Suyanto & Semanding & 120 \\
\hline 17 & Sakini & Semanding & 170 \\
\hline 18 & Suharli & Semanding & 175 \\
\hline 19 & Jasman & Prunggahan Wetan & 150 \\
\hline 20 & Abdul Rahman & Prunggahan Wetan & 175 \\
\hline 21 & Budi Sulistono & Prunggahan Wetan & $275 *$ \\
\hline 22 & Slamet Wahyudi & Prunggahan Wetan & $350 * *$ \\
\hline 23 & Priyanto & Prunggahan Wetan & 150 \\
\hline 24 & Marpuah & Prunggahan Wetan & $250 *$ \\
\hline 25 & Atmo & Prunggahan Wetan & 200 \\
\hline 26 & Eko & Prunggahan Wetan & 225 \\
\hline 27 & Tarno & Prunggahan Wetan & 200 \\
\hline 28 & Sukirlan & Prunggahan Wetan & 175 \\
\hline 29 & Warji & Prunggahan Wetan & 150 \\
\hline 30 & Sarju & Prunggahan Wetan & 200 \\
\hline
\end{tabular}


Tabel 2. Keragaan Pertanaman Terpilih dari Desa Prunggahan Wetan, Kecamatan Semanding, Kabupaten Tuban

\begin{tabular}{lccc}
\hline \multicolumn{1}{c}{ Karakter Tanaman } & \multicolumn{3}{c}{ Nama Pemilik } \\
\cline { 2 - 4 } & Slamet Wahyudi & Marpuah & Budi Sulistono \\
\hline Umur Tanaman (tahun) & 37 & 200 & 25 \\
Tinggi Tanaman (m) & 25 & 17 & 10 \\
Lingkar Batang (cm) & 145 & 242 & 119 \\
Lebar tajuk (m) & 8,98 & 11,38 & 7,4 \\
Percabangan & Rapat & Sedikit & Sedang \\
Produksi (kg/pohon) & 350 & 250 & 275 \\
Kesukaan $\quad$ konsumen & Sangat suka & Suka & Suka \\
terhadap rasa buah & & & Kurang sehat \\
Kesehatan Tanaman & Sehat & & Sehat \\
\hline
\end{tabular}

Berdasarkan data keragaan tanaman pada Tabel 2 dan informasi dari informan kunci serta pengamatan di lapang tentang tingginya permintaan buah duku oleh konsumen terhadap produksi duku milik Bapak Slamet Wahyudi serta rasa buah yang manis dan kualitas buah lebih bagus dibandingkan tanaman Ibu Marpuah dan Bapak Budi maka ditentukan tanaman duku milik Bapak Slamet Wahyudi sebagai Pohon Induk Tunggal (PIT). Sedangkan tanaman Ibu Marpuah, umur tanaman terlalu tua serta percabangan sedikit sehingga sulit untuk diambil entresnya. Tanaman bapak Budi masih kurang perawatan dan tanaman masih lebih muda (25 th) dibanding milik pak Slamet Wahyudi.

\section{Hasil Seleksi}

Hasil seleksi dari populasi tanaman duku yang ada di Kecamatan Semanding yang terletak di 3 desa yaitu Prunggahan Kulon, Prunggahan Wetan dan Semanding menampilkan bahwa pertanaman duku yang ada di Kecamatan Prunggahan Wetan lebih baik dibandingkan dengan yang ada di dua desa lainnya. Dengan demikian penilaian pohon induk dilanjutkan pada tanaman duku yang ada di Prunggahan Wetan dan terpilih 3 tanaman yaitu milik Bapak Slamet Wahyudi, Ibu 
Marpuah, serta Bapak Budi Sulistono. Dari ketiga tanaman tersebut nampak tanaman duku milik Ibu Marpuah memiliki umur yang paling tua lebih dari 150 tahun sehingga keragaan tanaman kurang sehat dan percabangannya sedikit sedangkan milik Bapak Budi Sulistono umur tanaman masih muda yaitu 25 tahun.

\section{Keragaan Tanaman yang Ada di Masyarakat}

Permasalahan yang muncul dalam usahatani duku Prunggahan yaitu tanaman duku yang ada selama ini berasal dari perbanyakan generatif (benih) sehingga setiap tanaman duku mempunyai sifat yang berbeda dengan tanaman lainnya dalam satu populasi. Oleh karena itu kualitas buah maupun produksi buah berbeda antar tanaman. Sedangkan permasalahan dalam upaya pengembangan luas areal tanaman duku Prunggahan adalah masalah non teknis dan teknis. Masalah non teknis dapat dipecahkan dengan memberi pengertian pada petani bahwa pengembangan luas areal tanaman bertujuan untuk meningkatkan produksi sehingga dapat memenuhi permintaan konsumen yang selalu meningkat di saat panen serta pengembangan luas areal juga terbatas dengan agroekologi yang sesuai bagi pertumbuhan duku Prunggahan. Sedangkan yang menjadi masalah teknis yaitu pengembangan tanaman perlu menggunakan bibit yang diperbanyak secara vegetatif sehingga diperoleh tanaman yang sama dengan induknya dari segi kualitas dan produksinya. Oleh karena itu diperlukan bibit duku yang berasal dari perbanyakan vegetatif sehingga tanaman hasil pengembangan memiliki kualitas buah yang unggul sesuai dengan pohon induk tunggalnya. Untuk itu sejak tahun 2004 telah dilakukan perbanyakan duku Prung gahan Tuban dengan menggunakan entres dari Pohon Induk Tunggal milik Bapak Slamet Wahyudi. Saat ini telah dikembangkan sekitar 1000 bibit duku Prunggahan hasil sambung di Keca matan Semanding, Kabupaten Tuban.

\section{Penampilan Tanaman Duku Prunggahan Tuban}

Penampilan secara umum tanaman duku Prunggahan Tuban cukup menarik karena bentuk tajuk tanaman seperti piramida tumpul dan 
percabangannya rapat sehingga terlihat rindang. Selain itu batang tanaman kekar dan perakarannya menonjol keluar terutama pada tanaman yang telah berumur puluhan tahun bahkan ratusan tahun sehingga batang bagian bawah tampak berlipat-lipat. Tinggi tanaman berkisar 12-17 $\mathrm{m}$ dan lingkar batang sekitar 1,45 m hingga 2,52 m. Bentuk tajuk tanaman seperti piramida tumpul dengan lebar tajuk $8,98 \mathrm{~m}$ hingga 13,2 $\mathrm{m}$, berdaun lebat dan bercabang banyak. Percabangan muncul sekitar 2,5-4 m dari permukaan tanah dengan jumlah cabang utama sekitar tujuh dan cabang sekunder sekitar 43. Warna kulit batang coklat tua dan permukaan batang tanaman tidak halus serta bagian bawah batang utama (dekat akar) berlipat-lipat. Bentuk daun majemuk dengan anak daun berbentuk lonjong dan ujungnya runcing. Warna daun bagian atas hijau tua dan bagian bawah hijau muda. Daun muda (pupus) berwarna hijau muda. Ukuran panjang daun sekitar $37 \mathrm{~cm}$ dan lebar daun $33 \mathrm{~cm}$, daun tebal dengan permukaan daun bergelombang.

Tanaman duku Prunggahan Tuban mulai berbunga sekitar bulan Juli-
Agustus dan panen pada bulan November-Januari. Lama bunga mekar sampai panen sekitar lima bulan, sedang lama bunga mekar sampai menjadi calon buah sekitar 3-5 minggu. Persentase bunga menjadi buah (fruit set) sekitar $60 \%$ per tandan. Umur simpan buah sekitar 5-7 hari dari panen pada suhu kamar.

\section{Keunggulan Kualitas Buah}

Duku Prunggahan Tuban memiliki beberapa keunggulan terutama dari segi rasa buah manis dan segar serta kemampuannya tumbuh dan berkem bang di dataran rendah iklim kering seperti wilayah Tuban. Hal inilah yang cukup menarik minat konsumen ataupun masyarakat di luar Tuban untuk mengembangkannya. Hasil pengamatan terhadap keragaan buah duku Prung gahan Tuban terutama dari rasa buah dan penampilan buah secara kese luruhan dibandingkan dengan dua vari etas unggul duku yaitu Srigading dan duku Kumpeh disajikan pada Tabel 3 berikut. 
Tabel 3. Penampilan Buah Duku Prunggahan Tuban, Duku Srigading dan Duku Kumpeh

\begin{tabular}{cccc}
\hline Karakter & $\begin{array}{c}\text { Duku Prunggahan } \\
\text { Tuban } *\end{array}$ & $\begin{array}{c}\text { Duku Srigading ** } \\
\text { (sudah dilepas) }\end{array}$ & $\begin{array}{c}\text { Duku Kumpeh ** } \\
\text { (sudah dilepas) }\end{array}$ \\
\hline Bentuk buah & Bulat telur & Bulat telur & Bulat telur \\
Berat per buah $(\mathrm{g})$ & $34,2-35,6$ & $18-36$ & $3,5-4,9$ \\
Panjang buah $(\mathrm{cm})$ & $3,98-4,32$ & 3,37 & $3,7-4,3$ \\
Diameter buah $(\mathrm{cm})$ & $3,14-3,54$ & 2,97 & $2,7-3,7$ \\
Berat daging buah $(\mathrm{g})$ & $26,4-27,2$ & - & - \\
Berat kulit buah $(\mathrm{g})$ & $5,5-5,7$ & - & - \\
Tebal kulit buah $(\mathrm{mm})$ & $0,9-1,7$ & $1-2$ & Kuning \\
Warna kulit buah & Kuning & Kuning & Putih bening \\
Warna daging buah & Bening & Bening & Manis legit \\
Rasa daging buah & Manis segar & Manis & - \\
Kadar gula $\left({ }^{\circ}\right.$ Brix $)$ & $19-21$ & 8,48 & Kenyal \\
Kadar asam $(\%)$ & 0,38 & 0,51 & - \\
Tekstur daging buah & Halus dan kenyal & Kenyal & \\
Jumlah biji per buah & 1- kadang-kadang tidak & 1 - kadang-kadang & \\
& ada & tidak ada & \\
\hline
\end{tabular}

\section{Keterangan :}

Sumber : *) Hasil analisa di Laboratorium Pasca Panen BPTP Jawa Timur

**) SK pelepasan varietas unggul duku Srigading dan duku Kumpeh tanda - berarti data kosong

Terlihat bahwa duku Prunggahan

Tuban memiliki ukuran buah yang besar serta rasa buah manis dan segar dengan kadar gula tinggi $\left(19-21^{\circ}\right.$ Brix $)$ dan kadar asam yang lebih rendah dibandingkan duku Srigading. Demikian juga jika dibandingkan dengan duku Kumpeh, varietas Prunggahan Tuban memiliki beberapa kelebihan antara lain ukuran buah besar dan rasa buah sangat manis yang dibuktikan dengan kadar gula yang tinggi (19-2 $1^{\circ}$ Brix). 
Tabel 4. Penampilan Buah Duku Prunggahan Tuban Dibanding Langsat Singosari

\begin{tabular}{ccc}
\hline Karakter & Duku Prunggahan Tuban * & $\begin{array}{c}\text { Langsat Singosari ** } \\
\text { (sudah dilepas) }\end{array}$ \\
\hline Bentuk buah & Bulat telur & Lonjong \\
Berat per buah $(\mathrm{g})$ & $34,2-35,6$ & $10,3-23,7$ \\
Panjang buah $(\mathrm{cm})$ & $3,98-4,32$ & - \\
Diameter buah $(\mathrm{cm})$ & $3,14-3,54$ & - \\
Berat daging buah $(\mathrm{g})$ & $26,4-27,2$ & - \\
Berat kulit buah $(\mathrm{g})$ & $5,5-5,7$ & $1-1,3$ \\
Tebal kulit buah $(\mathrm{mm})$ & $0,9-1,7$ & Kuning kecoklatan \\
Warna kulit buah & Kuning & Bening \\
Warna daging buah & Bening & Manis, sedikit masam, \\
Rasa daging buah & Sangat manis dan segar & segar \\
& & - \\
Kadar gula $\left({ }^{\circ}\right.$ Brix $)$ & $19-21$ & 0,95 \\
Kadar asam $(\%)$ & 0,38 & Halus \\
Tekstur daging buah & Halus dan kenyal & $0-2$ \\
Jumlah biji per buah & 1- kadang-kadang tidak ada &
\end{tabular}

Keterangan :

Sumber : 1) Hasil analisa di Laboratorium Pasca Panen BPTP Jawa Timur

2) SK pelepasan varietas unggul langsat Singosari tanda - berarti data kosong

Selain itu permukaan kulit buah duku Prunggahan Tuban sangat berbeda dengan Langsat Singosari yang sudah dilepas menjadi varietas unggul, demikian juga dengan bentuk buahnya. Langsat Singosari kulit buah lebih tipis dan bentuk buah lonjong, sedangkan duku Prunggahan bentuk buahnya bulat telur dan kulit buah lebih tebal (Tabel 4). Duku Prunggahan memiliki permukaan kulit buah yang kurang mengkilat dibanding langsat Singosari. Sedangkan buah duku Prunggahan yang tertampil pada foto saat kondisi buah terguyur air hujan sehingga tampak lebih mengkilat. Menurut Rupiah, et al. (2018), karakter morfologi yang membedakan duku dengan langsat adalah kondisi kanopi tanaman, adanya rambut pada baguan bawah dan atas daun, bentuk buah, ketebalan kulit buah, rasa buah, dan adanya getah pada buah yang telah masak.

\section{Preferensi Konsumen / Masyarakat}

Preferensi konsumen atau masyarakat terhadap buah duku Prunggahan Tuban sangat tinggi karena 
penampilan buah kuning menarik, rasa buah manis dan segar serta dapat tumbuh di dataran rendah iklim kering. Hal ini merupakan keunggulan utama yang dimiliki duku Prunggahan Tuban. Promosi pada berbagai expose produk hortikultura tingkat nasional juga membuktikan bahwa duku Prunggahan Tuban banyak diminati oleh pengun jung karena berbagai keunggulannya. Pemasaran buah sudah menyebar ke kota besar seperti Surabaya dan beberapa kota di Jawa Tengah. Selain itu hingga saat ini pemilik tanaman duku selalu kewalahan menerima pesanan karena permintaan konsumen sangat tinggi dan pada umumnya buah telah dipesan konsumen sebelum dipanen. Konsumen umumnya mendata ngi dan memilih sendiri buah duku yang ada di pohon.

\section{Uji Preferensi Konsumen}

Uji preferensi konsumen dilakukan dengan membandingkan buah duku Prunggahan Tuban dengan varietas unggul duku Sri Gading dari Tulungagung. Hasil uji organoleptik, buah duku Prunggahan Tuban mempunyai beberapa keunggulan dilihat dari bentuk, ukuran, warna, tekstur buah dengan kulit dan daging, rasa manis dan masam dan rasa secara keseluruhan. Ukuran buah rata-rata duku Prunggahan lebih besar dibanding dengan duku Sri Gading sehingga konsumen lebih menyukai, kesan yang diperoleh menunjukkan bahwa konsumen kurang menyukai buah duku dengan ukuran kecil.

Warna kulit memiliki kesan tersendiri bagi konsumen, karena penampakan warna kulit akan berpengaruh terhadap keputusan konsumen untuk mengambil keputusan mencicipi, merasakan atau kemudian membeli. Dengan warna kulit yang dimiliki duku Prunggahan yang kuning bersih mempunyai penampilan yang menarik sehingga rata-rata menyatakan suka. Warna daging buah buah duku Prunggahan nampak lebih bening seperti transparan pada tingkat kematangan optimal kemudian dibiarkan semalam setelah petik, kesan daging buah tanpa warna putih yang masih tersisa akan lebih menarik sehingga disukai konsumen. Hal ini ditunjang oleh kesadaran petani bahwa buah akan dipetik apabila warna kulit 
buah telah menunjukkan kuning merata pada seluruh permukaan, meskipun belum semua petani melakukannya.

Tekstur daging buah duku Prunggahan dengan duku Sri Gading memberikan kesan yang tidak jauh berbeda. Namun tekstur buah sebelum dikupas, duku Prunggahan lebih disukai konsumen, karena terasa lebih lunak/smooth daripada duku Sri Gading. Hal ini diduga disebabkan oleh ketebalan kulit yang rata-rata pada duku Sri Gading terasa lebih tebal dan keras.

Rata-rata selera konsumen buah terhadap rasa masih lebih banyak yang menyukai buah dengan rasa yang manis. Duku Prunggahan memiliki rasa lebih manis dan segar daripada Sri Gading. Dengan tingkat rasa masam yang hampir sama antara duku Prunggahan dengan Sri Gading menyebabkan nisbah rasa manis dengan rasa masam buah duku Prunggahan terasa lebih manis. Keseimbangan rasa tersebut dikombi nasi dengan kandungan air yang tinggi memunculkan kesan terpenuhi keinginan konsumen pada kesegaran rasa.

Tabel 5. Hasil Uji Organoleptik Buah Duku Prunggahan Tuban dan Duku Sri Gading

\begin{tabular}{|c|c|c|c|c|c|c|c|c|c|c|}
\hline \multirow{3}{*}{ Parameter } & \multicolumn{10}{|c|}{ Skor Tingkat Preferensi Konsumen } \\
\hline & \multicolumn{5}{|c|}{ Duku Prunggahan Tuban } & \multicolumn{5}{|c|}{ Duku Sri Gading } \\
\hline & 1 & 2 & 3 & 4 & 5 & 1 & 2 & 3 & 4 & 5 \\
\hline Bentuk buah & - & - & - & $\mathrm{V}$ & - & - & - & - & $\mathrm{V}$ & - \\
\hline Ukuran & - & - & - & - & $\mathrm{V}$ & - & - & - & $\mathrm{V}$ & - \\
\hline Warna kulit & - & - & - & - & V & - & - & - & $\mathrm{V}$ & - \\
\hline Warna daging & - & - & - & V & - & - & - & - & $\mathrm{V}$ & - \\
\hline Tekstur dengan kulit & - & - & - & - & V & - & - & - & $\mathrm{V}$ & - \\
\hline Tekstur daging & - & - & - & - & $\mathrm{V}$ & - & - & - & - & V \\
\hline Kandungan air & - & - & - & V & - & - & - & - & $\mathrm{V}$ & - \\
\hline Aroma & - & - & $\mathrm{V}$ & - & - & - & - & $\mathrm{V}$ & - & - \\
\hline Rasa manis & - & - & - & - & $\mathrm{V}$ & - & - & - & $\mathrm{V}$ & - \\
\hline Rasa masam & - & - & - & V & - & - & - & - & $\mathrm{V}$ & - \\
\hline Rasa keseluruhan & - & - & - & - & V & - & - & - & $\mathrm{V}$ & - \\
\hline
\end{tabular}




\section{Deskripsi Varietas Duku Prunggahan Tuban \\ Duku Prunggahan Tuban \\ memiliki deskripsi sebagaimana \\ terdapat pada Tabel 6 .}

Tabel 6. Deskripsi Varietas Duku Prunggahan Tuban

\begin{tabular}{|c|c|}
\hline Komponen Pengamatan & Hasil/ ukuran \\
\hline Asal tanaman & :Desa Prunggahan Wetan, kecamatan \\
\hline & Semanding, kabupaten Tuban Propinsi \\
\hline & Jawa Timur \\
\hline Umur tanaman & : 37 tahun \\
\hline Lebar tajuk & $: 8,98 \mathrm{~m}$ \\
\hline Bentuk tanaman/tajuk & : Piramida \\
\hline Tinggi tanaman & $: 15 \mathrm{~m}$ \\
\hline Lingkar batang & $: 145 \mathrm{~cm}$ \\
\hline Jumlah cabang utama & $: 7-9$ \\
\hline Jumlah cabang sekunder & $: 43-45$ \\
\hline Bentuk penampang batang & : Silindris, tidak rata/bergelombang \\
\hline Warna batang & : Coklat \\
\hline Bentuk daun & : daun majemuk, anak daun lonjong \\
\hline Ukuran daun (Panjang x Lebar) & $:(37-39 \mathrm{~cm}) \times(33-34 \mathrm{~cm})$ \\
\hline Ukuran anak daun (Panjang x Lebar) & $:(16,63-16,87 \mathrm{~cm}) \times(7,69-7,92 \mathrm{~cm})$ \\
\hline Panjang tangkai daun & $: 8,5-8,8 \mathrm{~cm}$ \\
\hline Susunan anak daun & : berselang-seling \\
\hline Tepi Daun & : Rata, agak bergelombang \\
\hline Ujung daun & : Lancip \\
\hline Permukaan daun & : Bergelombang \\
\hline Warna daun bagian atas & : Hijau tua \\
\hline Warna daun bagian bawah & :hijau muda \\
\hline Bentuk bunga & : tersusun dalam tandan \\
\hline Warna bunga & : mahkota bunga kuning, benang sari putih \\
\hline Jumlah bunga pertandan & : $86-92$ kuntum \\
\hline Diameter tangkai bunga & $: 0,33-0,35 \mathrm{~cm}$ \\
\hline Diameter kuncup bunga & $: 0,55-0,58 \mathrm{~cm}$ \\
\hline Diameter bunga mekar & $: 0,57-0,60 \mathrm{~cm}$ \\
\hline Umur tanaman asal biji, mulai berbunga & : $14-15$ tahun \\
\hline Lama bunga mekar menjadi calon buah & $: 3-5$ minggu \\
\hline Lama bunga mekar sampai panen & : 5 bulan \\
\hline Persentase bunga menjadi buah (fruitset) & $: 60 \%$ per tandan \\
\hline Produksi buah / pohon & : $300-350 \mathrm{~kg} /$ pohon \\
\hline Panjang tangkai buah & $: 2,2-3,3 \mathrm{~mm}$ \\
\hline Jumlah buah per tandan & $: 32-56$ buah \\
\hline Panjang tandan buah & $: 20-29 \mathrm{~cm}$ \\
\hline Bentuk buah & bulat telur \\
\hline Warna kulit buah matang & : kuning \\
\hline
\end{tabular}


Ketebalan kulit buah

Warna daging buah

Rasa daging buah

Kadar gula

Kadar asam (\%)

Aroma buah

Tekstur daging buah

Jumlah biji per buah

Bentuk biji

Bobot buah

Ukuran buah

Daya simpan pada suhu kamar

Nomor Registrasi/ Identitas Pohon Induk:

Keterangan
: $0,9-1,7 \mathrm{~mm}$

: jernih/ bening

: Segar dan manis

: $19-21^{\circ}$ Brix

: $0,36-0,38 \%$

: lembut

: halus dan kenyal

: 1 - kadang kadang tidak ada

: pipih lonjong

: besar : 34,2 - 35,6 gram

: kecil : 20.4- 21,8 gram

: panjang : $3,98-4,32 \mathrm{~cm}$

: diameter : $3,40-3,54 \mathrm{~cm}$

: 7 - 10 hari setelah panen

: PIT/DK/I/JTM/08 , milik bapak Slamet

Wahyudi, desa Prunggahan Wetan, kecamatan Semanding, kabupaten TubanJawa Timur

: Tumbuh baik pada dataran rendah, $4-10$ $m$ dpl dengan rejim kelembaban agak kering dan air tanah dangkal

Bapak Slamet Wahyudi, Ibu Marpuah dan Bapak Budi Sulistiono. Selanjutnya atas dasar keragaan tanaman dan kesukaan konsumen terhadap buah, terpilih duku milik Bapak Slamet Wahyudi sebagai Pohon Induk Tunggal (PIT).

\section{DAFTAR PUSTAKA}

Allard, R. W. 1989. Pemuliaan Tanaman

Universitas (terjemahan). Jogjakarta. Gajahmada. karakter produksi tanaman berdasarkan kuantitas dan kualitas buah. Atas dasar ketiga karakter tersebut, maka dipilih tiga tanaman dengan produksi tertinggi sebagai tanaman induk awal, yaitu milik 
Kantor Informasi Penyuluhan Pertanian dan Kehutanan Kabupaten Tuban. 2004. Program penyuluhan pertanian.

Rupiah, L. Hanum, Z. P. Negara, Z. Dahlan dan I. Yustian. 2018. Morphological Diversity of Lansiumdomesticum Corr in South Sumatra. Science Technology Indonesia. 3 (1): 4144.

Saraswati, D.P, Suyamto, D. Setyorini dan A.G. Pratomo. 2001. Zona Agroekologi Jawa Timur. Brosur BPTP Jawa Timur.

Susilawati, S. 2017. The Variability of Lansium domesticum corr. (Duku) Accessions Based on the Characters of Morphology, Physiology and Anatomy in Musi Rawas Regency, South Sumatra Indonesia. Malaysian Applied Biology. 46(4):85-90. Abstract. Diakses 15 Maret 2018.

Verheij, E.W.M. and R.E. Coronell. 1997. Prosea (Plant Resources of South East Asia) 2. Edible Fruits and Nuts. 